\title{
Evaluation of Glyphosate Resistance in Transgenic Lettuce
}

\author{
Russell T. Nagata, ${ }^{1}$ Joan A. Dusky, ${ }^{1}$ Robert J. Ferl, Antonio C. Torres, ${ }^{2}$ and Daniel J. Cantliffe \\ Horticultural Sciences Department, University of Florida, Institute of Food and Agricultural Sciences, \\ 1251 Fifield Hall, P.O. Box 110690, Gainesville, FL 32611-0690
}

AdDitional INDEX WORDS. genetic engineering, herbicide resistance, Lactuca sativa, plant breeding, plant transformation

\begin{abstract}
Six transgenic 'South Bay' lettuce lines (Lactuca sativa L.) with elevated levels of 5-enolpyruvyl shikimate-3phosphate synthase (EPSPS) were evaluated for tolerance to the herbicide glyphosate. The six lines were selected from $\approx 150$ independent transformation events using an Agrobacterium tumefaciens system. Three assay methods were used to identify gene expression with regard to glyphosate resistance. Leaf disks of the transgenic lines were cultured on media containing 0 to $1280 \mu \mathrm{m}$ glyphosate. Leaf disks of the control had lower dry weight (DW) at $40 \mu \mathrm{M}$ and greater glyphosate than all the transgenic lines. The transgenic lines continued to grow even at $1280 \mu \mathrm{M}$. Plants 21 days old were sprayed in the greenhouse with rates of glyphosate at 0 to $35.84 \mathrm{~kg} \cdot \mathrm{ha}^{-1}$. DW of all the lines were similar to the control, with a few exceptions, at glyphosate concentrations from 0 to $0.56 \mathrm{~kg} \cdot \mathrm{ha}^{-1}$. At 2.24 to $8.96 \mathrm{~kg} \cdot \mathrm{ha}^{-1}$ all of the transgenic lines had DW greater than the control, while

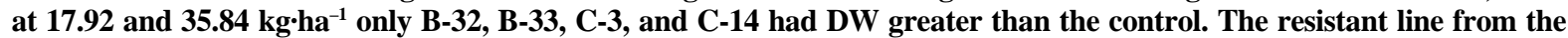
greenhouse experiment, B-32, grew normally in field trials at the highest glyphosate rate, $17.92 \mathbf{~ k g} \cdot \mathrm{ha}^{-1}$, while control plants died at $0.56 \mathrm{~kg} \cdot \mathrm{ha}^{-1}$ glyphosate. Lines A-11 and C-3 had lower DW than B-32 at $2.24 \mathrm{~kg} \cdot \mathrm{ha}^{-1}$ glyphosate and greater. While leaf disk assays can identify potential transformed lines expressing the EPSPS and glyphosate oxidase (GOX) gene, and greenhouse screening can evaluate seedling vigor after glyphosate application, field trials are necessary to evaluate plant growth and yield through the growing season. Chemical name used: N-(phosphono-methyl) glycine (glyphosate).
\end{abstract}

Weed control in lettuce can amount to a significant cost of lettuce (Lactuca sativa) production, ranging from $\$ 500$ to $\$ 1,975$ per hectare (Dusky and Stall, 1996). At present, chemical, manual and/or mechanical means are used individually or in combination for control of weeds in lettuce. Each method has its benefit and shortcomings. Chemical control procedures are easy to use and do little to disturb the roots of the growing lettuce plants. However, rates of the approved herbicides, which do not cause phytotoxicity in lettuce, usually will not provide $100 \%$ control of all weeds (Dusky et al., 1988; Dusky and Stall, 1996). Also, the narrow window of efficacy versus phytotoxicity of some chemicals now in use can result in severe crop loss (Dusky and Stall, 1995). Manual or mechanical weed control procedures disturb the soil surface and potentially the crop roots. This negatively affects lettuce growth resulting in reduced yields and head quality (Shrefler et al., 1994).

Currently, standard procedures to evaluate crops for tolerance to a particular herbicide include evaluating efficacy of weed control at various application rates and correlating this to crop phytotoxicity. When herbicide efficacy and crop tolerance are identified, registration of the herbicide for the crop may be pursued. Torres et al. (1999) incorporated a 5-enolpyruvyl shikimate-3-phosphate synthase (EPSPS) gene which confers tolerance to the herbicide glyphosate into theiceburg lettuce cultivar 'South Bay'. The herbicide glyphosate (Round-Up) was identified for its broad spectrum effectiveness to control weeds and its low environmental impact to nontarget organisms. These transgenic lines were not evaluated for field resistance to glyphosate nor the horticultural characteristics of the

Received for publication 6 July 1999. Accepted for publication 26 June 2000. Florida Agricultural Experiment Station journal series R-06901. The cost of publishing this paper was defrayed in part by the payment of page charges. Under postal regulations, this paper therefore must be hereby marked advertisement solely to indicate this fact.

${ }^{1}$ University of Florida, Institute of Food and Agricultural Sciences, Everglades Research and Education Center, P.O. Box 8003, Belle Glade, FL 33430.

${ }^{2}$ Current address: EMBRAPA/CNPH, P.O. Box 218, Brasilia-DF, Brazil 70359970 mature head after application of glyphosate. Selection of expressed tolerances can be affected by age of the plant material being tested. Different tests might result in different interpretations of herbicide tolerance based on the method performed. Gene number and position effect can all affect expression of the character under question, thus, potentially altering gene expression and/or normal plant growth. This paper reports results of laboratory, greenhouse, and field tests to determine glyphosate tolerance in several transgenic lettuce lines.

\section{Materials and Methods}

All transgenic lines were derived from 'South Bay' lettuce via an Agrobacterium tumefaciens mediated transfer of the 5enolpyruvyl shikimate-3-phosphate synthase (EPSPS) and glyphosate oxidase (GOX) genes using the procedure described by Torres et al. (1993). Two different A tumefaciens vectors, pMON 17194 and pMON 17204 (Monsanto Chemical Co, St. Louis, Mo.) were used. Vector pMON 17194 (Kanamycin resistant gene, glyphosate oxidase, and EPSPS activity) was used in group A and C, while vector pMON 17204 (Kanamycin resistant gene, $\beta$-glucuronidase, glyphosate oxidase, and EPSPS activity) was used for group B. The numbered lines A-11, A-13, B-32, B$33, \mathrm{C}-3$, and C-14 were selected following preliminary screening procedures for resistance to glyphosate and the homozygous presence of the EPSPS and GOX genes (Torres et al., 1999). Nontransformed 'South Bay' was used as the control for all experiments reported in this paper. The source of glyphosate was Rodeo (Monsanto Chem. Co.), which is manufactured without a surfactant added. When a surfactant was required, Induce (Helena Chemical Co., Memphis, Tenn.) was added at the rate of $0.25 \%(\mathrm{v} / \mathrm{v})$ to each solution.

LEAF DISK ASSAY. The fifth and/or sixth fully expanded leaf of 4-week-old 'South Bay' control plants and the six transgenic lettuce lines were excised near the stem, rinsed under running tap water and disinfected in $0.5 \%(\mathrm{v} / \mathrm{v})$ sodium hypochlorite solution containing $0.05 \%(\mathrm{v} / \mathrm{v})$ Tween 20 for $10 \mathrm{~min}$. The leaves were 
Table 1. Ddry weight of 28-d-old leaf disks of 'South Bay' (SB) lettuce (control) and six transgenic lettuce lines grown on MS media supplemented with varying rates of glyphosate herbicide. Data for all five experiments pooled.

\begin{tabular}{|c|c|c|c|c|c|c|c|c|}
\hline \multirow{2}{*}{$\begin{array}{l}\text { Glyphosate } \\
(\mu \mathrm{M})\end{array}$} & \multicolumn{8}{|c|}{ Transgenic line [dry wt (mg)] } \\
\hline & SB & A-11 & A-13 & B-32 & B-33 & $\mathrm{C}-3$ & C-14 & $\mathrm{LSD}^{\mathrm{z}}$ \\
\hline 0 & 87 & 92 & 86 & 92 & 98 & 100 & 83 & 26 \\
\hline 10 & 83 & 73 & 85 & 79 & 91 & 98 & 74 & 23 \\
\hline 20 & 62 & 96 & 85 & 83 & 92 & 100 & 86 & 25 \\
\hline 40 & 34 & 57 & 58 & 61 & 75 & 63 & 72 & 22 \\
\hline 80 & 16 & 74 & 78 & 75 & 80 & 92 & 76 & 24 \\
\hline 160 & 15 & 76 & 86 & 88 & 85 & 90 & 78 & 27 \\
\hline 320 & 8 & 54 & 58 & 54 & 69 & 76 & 53 & 19 \\
\hline 500 & 9 & 46 & 54 & 45 & 59 & 72 & 49 & 19 \\
\hline 640 & 9 & 47 & 50 & 46 & 55 & 66 & 64 & 16 \\
\hline 1000 & 8 & 63 & 60 & 79 & 70 & 77 & 66 & 18 \\
\hline 1280 & 8 & 51 & 53 & 66 & 64 & 68 & 70 & 17 \\
\hline
\end{tabular}

${ }^{\mathrm{z}}$ Mean separation within columns by LSD, $P=0.05$.

rinsed with sterile deionized water three times using enough water to cover the leaves in the beaker. A single row of leaf disks were cut with a $1-\mathrm{cm}$-diameter cork hole borer from the margins of individual leaves. Three leaf disks, each from a different leaf on the same line were placed into a $90-\mathrm{mm}$ petri dish containing $20 \mathrm{ml}$ media with 0 , $10,20,40,80,160,320,500,640,1000$, or $1280 \mu$ м active ingredient (a.i.) of glyphosate amine salts. The media also contained MS salts (Murashige and Skoog, 1962); Gamborg's B-5 vitamins (Gamborg et al., 1968); sucrose at $30.0 \mathrm{~g} \cdot \mathrm{L}^{-1}$; agar at $7.0 \mathrm{~g} \cdot \mathrm{L}^{-1}$; indoleacetic acid at $0.876 \mathrm{mg} \cdot \mathrm{L}^{-1}$; and benzyladenine at $0.495 \mathrm{mg} \cdot \mathrm{L}^{-1}$. Media $\mathrm{pH}$ was adjusted to 5.8 with $0.5 \mathrm{~N} \mathrm{HCl}$ or $\mathrm{KOH}$ solution as needed. A stock solution of glyphosate was filter sterilized and added to the media just prior to filling the petri dishes. Individual petri dishes were sealed with parafilm to reduce the potential for contamination of the cultures.

The petri dishes containing the leaf disks were incubated at $26 \pm$ $2{ }^{\circ} \mathrm{C}$ with a daily $14-\mathrm{h}$ photoperiod of $2 \mu \mathrm{mol} \cdot \mathrm{m}^{-2} \cdot \mathrm{s}^{-1}$ provided by cool-white fluorescent lamps. After 4 weeks, the individual leaf disks were weighed, dried at $70{ }^{\circ} \mathrm{C}$ for $72 \mathrm{~h}$ and reweighed. The experiment was repeated a total of five times with two replications in each repeat. Data were subjected to analysis of variance procedures and means separated by Fisher's LSD (SAS Institute, Inc., 1996).

SEEDLING ASSAY. Two seeds from each line were sown in a single width-wise row of a Todd Planter flat (No. 125) filled with Fafard
\#2 growing medium (C. Fafard, Springfield, Mass). The flats were watered and kept in a glass greenhouse at days/nights of $32 / 18^{\circ} \mathrm{C}$. At $7 \mathrm{~d}$ postsowing, individual cells in the flat were thinned to a single plant. At $21 \mathrm{~d}$ postsowing, seedlings from individual flats were sprayed with glyphosate at $0,0.018,0.035,0.07,0.14,0.28$. 0.56, $1.12,2.24,4.48$, or 8.96, plus $0.25 \% \mathrm{v} / \mathrm{v}$ surfactant as in Expt. 1. To establish a better kill curve for the transgenic lines, two additional glyphosate concentrations, 17.72 or $35.84 \mathrm{~kg} \cdot \mathrm{ha}^{-1}$ were added, while the 0.018 and 0.035 concentrations were omitted from Expts. 2 and 3. Application of glyphosate solutions were made with a $\mathrm{CO}_{2}$ backpack sprayer operated at $2.07 \times 10^{5} \mathrm{~Pa}$, equipped with $\mathrm{T}$-jet 8004 flat fan nozzles and applied above the plant canopy at the rate of $332 \mathrm{~L} \cdot \mathrm{ha}^{-1}$. Two weeks after treatment, five plants from the center of each row were harvested individually at the soil surface level and dried at $40{ }^{\circ} \mathrm{C}$ for $5 \mathrm{~d}$. Sample dry weight (DW) was then recorded. The planting, treatment and harvest dates were 20 Oct. 1994, 9 Nov. 1994, 22 Nov. 1994; 6 Dec. 1994, 21 Dec. 1994, 4 Jan. 1995, 17 Jan. 1995, 8 Feb. 1995, and 22 Feb. 1995, respectively, for the three runs.

The experiment was repeated a total of three times, with four replications each time the experiment was conducted. The flats were arranged in a randomized complete block design for each experiment. Data were analyzed by Fisher's LSD.

Whole-PLANT ASSAY. 'South Bay' and the transgenic lines A-11, B-32, and C-3 were used for Expt. 1 and 'South Bay' and line B-32 were used for Expt. 2. Line B-32 was selected for Expt. 2 due to its

Table 2. Dry weight of 'South Bay' (SB) lettuce (nontransgenic) and six transgenic lettuce lines $14 \mathrm{~d}$ after glyphosate treatment of 21-d-old lettuce plants grown in a greenhouse. ${ }^{\mathrm{z}}$ Data from Expt. 3.

\begin{tabular}{|c|c|c|c|c|c|c|c|c|}
\hline \multirow{2}{*}{$\begin{array}{l}\text { Glyphosate } \\
\left(\mathrm{kg} \cdot \mathrm{ha}^{-1}\right)\end{array}$} & \multicolumn{8}{|c|}{ Transgenic lines [dry wt (mg)] } \\
\hline & SB & A-11 & A-13 & B-32 & B-33 & $\mathrm{C}-3$ & C-14 & $\mathrm{LSD}^{\mathrm{z}}$ \\
\hline$\overline{0}$ & 303 & 216 & 219 & 318 & 263 & 267 & 283 & 115 \\
\hline 0.07 & 449 & 320 & 282 & 348 & 336 & 423 & 388 & 79 \\
\hline 0.14 & 353 & 292 & 293 & 401 & 389 & 449 & 468 & 88 \\
\hline 0.28 & 272 & 352 & 368 & 281 & 238 & 301 & 320 & 104 \\
\hline 0.56 & 331 & 397 & 405 & 466 & 340 & 463 & 519 & 88 \\
\hline 1.12 & 188 & 342 & 410 & 251 & 249 & 378 & 395 & 66 \\
\hline 2.24 & 121 & 284 & 260 & 237 & 169 & 242 & 292 & 43 \\
\hline 4.48 & 103 & 354 & 365 & 427 & 341 & 309 & 499 & 83 \\
\hline 8.96 & 73 & 191 & 260 & 324 & 216 & 250 & 366 & 70 \\
\hline 17.92 & 78 & 140 & 144 & 372 & 198 & 229 & 430 & 69 \\
\hline 35.84 & 76 & 137 & 115 & 301 & 149 & 147 & 324 & 64 \\
\hline
\end{tabular}

${ }^{\mathrm{z}}$ Mean separation within columns by LSD, $P=0.05$. 
Table 3. Dry weight of field-grown 'South Bay' (SB) lettuce (nontransgenic) and three transgenic lettuce lines treated with glyphosate herbicide at $21 \mathrm{~d}$ postsowing and harvested. Data from Expt. 2.

\begin{tabular}{|c|c|c|c|c|c|}
\hline \multirow{2}{*}{$\begin{array}{l}\text { Glyphosate } \\
\left(\mathrm{kg} \cdot \mathrm{ha}^{-1}\right)\end{array}$} & \multirow[b]{2}{*}{ SB } & \multicolumn{4}{|c|}{ Transgenic lines [dry wt $(\mathrm{g})]$} \\
\hline & & A-11 & B-32 & $\mathrm{C}-3$ & $\mathrm{LSD}^{2}$ \\
\hline 0 & 15.5 & 14.5 & 27.0 & 23.2 & 10.6 \\
\hline 0.07 & 17.2 & 14.0 & 28.1 & 21.3 & 6.6 \\
\hline 0.14 & 3.5 & 11.2 & 24.1 & 26.6 & 10.7 \\
\hline 0.56 & --- & 9.4 & 26.5 & 22.7 & 6.4 \\
\hline 1.12 & --- & 11.9 & 28.1 & 23.5 & 12.3 \\
\hline 2.24 & --- & 11.5 & 30.2 & 17.7 & 7.4 \\
\hline 4.48 & --- & 7.3 & 28.2 & 15.8 & 11.3 \\
\hline 8.96 & --- & --- & 28.7 & 9.3 & 3.8 \\
\hline 17.92 & --- & --- & 21.5 & --- & --- \\
\hline
\end{tabular}

${ }^{\mathrm{z}}$ Mean separation within rows by LSD, $P=0.05$.

potential for tolerance to glyphosate and excellent horticultural qualities which were similar to the original 'South Bay'. Experiment 1 was conducted two times, each time with four replications, and was sown on 20 Oct. 1994 and 6 Feb. 1995. At 4 weeks postsowing, glyphosate treatments of $0,0.14,0.56,1.12,2.24,4.48,8.96$, or $17.72 \mathrm{~kg} \cdot \mathrm{ha}^{-1}$ were applied over the crop canopy. Application of herbicide solutions were made $30 \mathrm{~cm}$ above the plant canopy as described above. Five heads from the center of each plot were harvested 4 Jan. and 22 Apr. 1995, respectively, for each trial. The lettuce heads were trimmed to marketable size as defined by USDA standards (U.S. Dept Agr., 1973). The heads were chopped individually into $3 \times 3 \mathrm{~cm}$ pieces or smaller and individual leaf layers separated by mixing. The samples were placed in brown paper bags and dried at $40^{\circ} \mathrm{C}$. The samples were mixed daily to promote faster drying of the leaves and prevent decay. When the leaves were dry (5 to $8 \mathrm{~d}$ ), the samples were weighed.

Experiment 2 was conducted three times, with four replications each time it was conducted. Seeds were sown initially 2 Feb. 1996 and a second time $16 \mathrm{Feb}$. Experiment 2 was conducted similar to the first, except treatment rates of glyphosate were $0,0.56,1.12$, $2.24,4.48$, or $17.72 \mathrm{~kg} \cdot \mathrm{ha}^{-1}$ with $0.25 \% \mathrm{v} / \mathrm{v}$ surfactant. Spray timing and procedures were the same as mentioned previously.

All field plantings were conducted on a Pahokee muck (euic, hyperthermic Lithic Medisaprist) at the University of Florida, Institute of Food and Agricultural Sciences, Everglades Research and Education Center, Belle Glade. Guidelines for conducting field plantings of transgenic plant material were followed according to U.S. Dept. of Agriculture and University of Florida Institutional Biosafety Committee Guidelines. Culture and management of the lettuce crop followed standard practices for the Everglades Agricultural Area (EAA). Fertilizer inputs were based on preplant soil test recommendations (Hochmuth et al., 1994). All plantings were made on $15 \mathrm{~cm}$ raised beds on $90 \mathrm{~cm}$ centers. Each plot consisted of a 6.1 $\mathrm{m}$ section of bed. Two lettuce seeds were planted every $30 \mathrm{~cm}$ in a single row down the center of each bed by hand. The plots were arranged in a randomized complete block design. At the four-leaf stage the seedlings were thinned to a single plant. Pest and disease problems were controlled following recommendations in the Vegetable Production Guide for Florida (Maynard and Hochmuth, 1995).

Five heads from each plot were harvested 10 and 30 Apr. 1996 for run one and two, respectively, and trimmed to marketable heads (U.S. Dept. of Agriculture, 1973). FW (all above ground green leaves and head) and fresh trimmed marketable head weights were recorded as yield then the heads were dried and weighed as described previously.

\section{Results and Discussion}

LEAF DISK ASSAY. Leaf disk DWs were significantly reduced in the control at $20 \mu \mathrm{m}$ glyphosate when compared to lines A-11, B-33, and C-3 (Table 1). Similar weight reductions in control disks continued at glyphosate levels $>40 \mu \mathrm{M}$ when compared to all the transgenic lines. Transgenic lines had only slight differences among the lines in DWs when leaf disks were grown at all glyphosate levels $>40 \mu \mathrm{M}$.

For all transgenic lines, the highest glyphosate concentration $(1280 \mu \mathrm{M})$ was not lethal to the leaf disks. Control leaf disks were killed at $320 \mu \mathrm{m}$ glyphosate and higher. All transgenic lettuce leaf disks survived all levels of glyphosate with callus growth around the margins of the disks. At lower glyphosate concentrations $(<320 \mu \mathrm{M})$ the callus mass covered the entire surface of the disk and shoots were seen growing from the callus mat. This indicated that a concentration of glyphosate $>320 \mu \mathrm{M}$ has inhibitory effects in organogenesis preventing shoot differentiation. However, callus growth continued in medium containing up to $1280 \mu \mathrm{M}$ glyphosate. The differences in response of dry matter accumulation among those lines suggested distinct categories of transgene tolerance to glyphosate concentration.

SEEDLING ASSaY. Three experiments were conducted with seedlings grown in the greenhouse. Glyphosate levels in the second and third experiments were increased to $35.8 \mathrm{~kg} \cdot \mathrm{ha}^{-1}$ glyphosate in an attempt to establish greater differences in DW among the transgenic lines. Since trends for all three experiments were similar, only the results from Expt. 3 containing the highest glyphosate concentration applied will be discussed (Table 2). Seedling DWs in the nontransgenic seedlings were less than those from lines C- 3 and C-14 at 0.14 and $0.56 \mathrm{~kg} \cdot \mathrm{ha}^{-1}$ glyphosate. At $1.12 \mathrm{~kg} \cdot \mathrm{ha}^{-1}$ glyphosate, controlDW was less than that from lines A-11, A-13, C-3, and C-14. At 2.24 to $8.96 \mathrm{~kg} \cdot \mathrm{ha}^{-1}$ all transgenic lines had greater DWs than the control. At glyphosate levels above $8.96 \mathrm{~kg} \cdot \mathrm{ha}^{-1}$ only the $\mathrm{B}$ and $\mathrm{C}$ lines maintained DWs greater than the control. The transgenic lines B-32 and $\mathrm{C}-14$ retained the greatest DW values at the highest glyphosate concentration $\left(35.8 \mathrm{~kg} \cdot \mathrm{ha}^{-1}\right)$.

WhOLE-PLANT ASSAY. For weed control using glyphosate in a commercial lettuce field at the three to four leaf stage, it is estimated that application rates of 0.28 to $0.56 \mathrm{~kg} \cdot \mathrm{ha}^{-1}$ are needed for control of annual weeds and 0.56 to $1.12 \mathrm{~kg} \cdot \mathrm{ha}^{-1}$ for perennial weeds. Plant vigor before glyphosate application measured as accumulated DW was similar among lettuce lines A-11, C-3, and the control (Table 3). DWs of control plants were unaffected by glyphosate application at the $0.14 \mathrm{~kg} \cdot \mathrm{ha}^{-1}$ rates compared to lines A-11 and C-3. Line B-32 retained significantly greater DWs than all the other lines at 0 and 
Table 4. Fresh weight, fresh trim, and trim dry weight of 'South Bay' lettuce (control) and transgenic lettuce line B-32 at harvest maturity treated with different rates of the herbicide glyphosate. Plants treated $21 \mathrm{~d}$ postsowing.

\begin{tabular}{|c|c|c|c|c|c|c|c|c|c|}
\hline \multirow{2}{*}{$\begin{array}{l}\text { Glyphosate } \\
\left(\mathrm{kg} \cdot \mathrm{ha}^{-1}\right)\end{array}$} & \multicolumn{3}{|c|}{ Fresh wt (g) } & \multicolumn{3}{|c|}{ Trim wt (g) } & \multicolumn{3}{|c|}{ Dry wt $(\mathrm{g})$} \\
\hline & SB & B-32 & LSD & SB & B-32 & LSD & SB & B-32 & LSD \\
\hline 0.0 & $753.5^{z}$ & 672.8 & 68.1 & 531.2 & 506.0 & 47.7 & 21.5 & 21.6 & 1.9 \\
\hline 0.56 & 11.8 & 730.5 & 39.7 & $\mathrm{NA}^{\mathrm{y}}$ & 537.3 & & NA & 21.4 & \\
\hline 1.12 & Dead & 681.5 & & NA & 482.4 & & NA & 19.4 & \\
\hline 2.24 & Dead & 723.2 & & NA & 514.0 & & NA & 21.3 & \\
\hline 4.48 & Dead & 763.6 & & NA & 559.1 & & NA & 21.7 & \\
\hline 17.92 & Dead & 765.9 & & NA & 563.6 & & NA & 23.0 & \\
\hline
\end{tabular}

${ }^{\mathrm{z}}$ Means separation within columns by LSD, $P=0.05$.

y Not available.

$0.07 \mathrm{~kg} \cdot \mathrm{ha}^{-1} \mathrm{glyphosate}$. All control plants were killed at glyphosate rates $\geq 0.56 \mathrm{~kg} \cdot \mathrm{ha}^{-1}$ and higher. Transgenic lettuce line B-32 was unaffected by glyphosate applications as high as $17.92 \mathrm{~kg} \cdot \mathrm{ha}^{-1}$. DWs of line A-11 at the 0.14 to $1.12 \mathrm{~kg} \cdot \mathrm{ha}^{-1}$ rates were less than those of the B-32 and C-3 lines, and at glyphosate rates of 8.96 and 17.92 $\mathrm{kg} \cdot \mathrm{ha}^{-1}, \mathrm{~A}-11$ plants were killed.

In the second field experiment, line B-32 and 'South Bay' were compared directly for total DW, marketable trimmed head weight, and DW of marketable trimmed heads. Control plants were killed by all levels of glyphosate applied, while the B-32 line survived all glyphosate levels up to $17.92 \mathrm{~kg} \cdot \mathrm{ha}^{-1}$ (Table 4). Fresh and trim weights of B-32 treated with glyphosate at 4.48 or $17.92 \mathrm{~kg} \cdot \mathrm{ha}^{-1}$ were in fact, greater than the control. None of the plants treated with glyphosate appeared morphologically different than the nontreated control plants.

Torres et al. (1999) have reported the usefulness of the leaf disk assay for screening glyphosate resistance in transgenic lettuce lines. In the present work, DWs of control leaf disks were reduced by glyphosate while several transgenic lines, namely B-32 and C-3, were unaffected by fairly high levels of glyphosate. Growth of Aline leaf disks was generally adversely affected by glyphosate in the media. These same comparisons were observed from the greenhouse seedling assay and in the field assays. Although better than the control, the vigor and glyphosate resistance of the A lines were generally less than the $\mathrm{B}$ and $\mathrm{C}$ lines. The $\mathrm{A}$ and $\mathrm{C}$ lines had the same vector, pMon 17194.

Thus, initial screening for glyphosate resistance in transgenic lines can be accomplished by leaf disk assay. However, in order to better predict field performance, the greenhouse screen can give further evidence to seedling vigor as well as survival of the transgenics. After using the proper selection protocol, the more costly field trials must be conducted in order to ascertain yield and quality traits of the new transgenic lines, as well as efficacy of the glyphosate plant herbicide resistance system. In the present work, glyphosate-tolerant lines of lettuce with the horticultural characteristics of the common commercial cultivar 'South Bay' for the EAA were identified.

\section{Literature Cited}

Dusky, J.A. and W.M. Stall. 1995. Weed management practices for lettuce production using Imazethapyr. Proc. Fla. State Hort. Soc. 108:204-207.

Dusky, J.A. and W.M. Stall. 1996. Evaluation of Imazethapyr for weed control in leafy vegetable crops. Weed Technol. 10:253-257.

Dusky, J.A., W.M. Stall, and J.M. White. 1988. Evaluation of herbicides for weed control in Florida lettuce production. Proc. Florida State Hort. Soc. 101:367-370.

Gamborg, O.L., R.A. Miller, and K. Oajima. 1968. Nutrient requirements of suspensions of soybean root cells. Expt. Cell Res. 50:151158.

Hochmuth, G., E. Hanlon, R. Nagata, G. Snyder, and T. Schueneman. 1994. Crisphead lettuce: Fertilization recommendations for crisphead lettuce grown on organic soils in Florida. Univ. Fla. Inst. Food Agr. Sci. Coop. Ext. Serv. Bul. SP 153.

Maynard, D.N. and G.J. Hochmuth (eds.). 1995. Vegetable production guide for Florida. Univ. Fla. Inst. Food Agr. Sci. Coop. Ext. Serv. Circ. SP-170.

Murashige, T. and F. Skoog. 1962. A revised medium for rapid growth and bioassays with tobacco tissue cultures. Physiol. Plant. 15:473-479.

SAS Institute, Inc. 1996. SAS release 6.12 ed. SAS Inst., Cary, N.C.

Shrefler, J.W., D.G. Shilling, J.A. Dusky, and B.J. Brecke. 1994. Influence of phosphorus fertility on intra and interspecific interference between lettuce (Lactuca sativa) and spiny amaranth (Amaranthus spinous). Weed Sci. 42:574-578.

Torres, A.C., D.J. Cantliffe. B. Laughner, M. Bieniek, R. Nagata, M. Ashraf, and R.J. Ferl. 1993. Stable transformation of lettuce cultivar 'South Bay' from cotyledon explants. Plant Cell Tissue Organ Cult. 34:279-285.

Torres, A.C., R.T. Nagata, R.J. Ferl, T.A. Bewick, and D.J. Cantliffe. 1999. In vitro assay selection of glyphosate resistance in lettuce. J. Amer. Soc. Hort. Sci. 124:86-89.

U.S. Department of Agriculture. 1973. USDA standards for grades of lettuce. USDA Mktg. Serv., Wash., D.C. 